J. Environ. Sci.

Institute of Environmental Studies and Research - Ain Shams University

\title{
HEAVY METALS CONTENT AND BACTERIAL LOAD OF SOME SPICES IMPORTED FROM VARIOUS ORIGINS
}

\author{
Reham Y. Mohamed ${ }^{(1)}$; Mohamed F. Khallaf ${ }^{(2)}$; Farouq M. El-Talawi ${ }^{(3)}$ \\ and Hamdy A.Mahdy (1)
}

1) National Nutrition Institute (NNI), Garden City, Cairo, Egypt 2) Fac. Agric., Ain Shams Univ 3) Institute of Environmental Studies \& Researches, Ain Shams Univ.

\begin{abstract}
The use of spices and other herbs has increased markedly in most regions of the world, including Europe and North America. Heavy metals have bioimportance as trace elements but the biotoxic effects of many of them in human biochemistry are of great concern. Spices can easily be contaminated by heavy metals from type of soil for cultivation,fertilizers and source of water used for irrigation.The effect of cultivation origin (importation area ; i.e American and /or Asian origins)was studied to determine the heavy metals content in addition to bacterial load of four imported spices( nutmeg, cinnamon, black pepper and allspice ) avilabale in Egyptian market. Moisture content did not affect according to its origin ranged between (9.96 to $11.36 \%$ ) in case of nutmeg. Regarding to cinnamon spice, moisture content possess no difference when it determined in either China or Mexico origin. Similar pattern was detected in case of Sri Lanka as well as India (from Asia) and Brazil (from America). When allspice was considered,only that imported from India did not significantly differed with corresponding one that imported from Mexico.In the same time (USA)sample was completely differed than that of other investigated samples.Regarding to the protein content of different investigated spices, there is no significant difference owing to its origin in case of nutmeg spice. Both of Asian cinnamon as well as allspice spices had no significant as affected by origin country. Similar finding was noticed in case of American black pepper. Concerning the fat content of various imported spices significant differences were detected between samples except of American imported cinnamon.The highest fat content was found in nutmeg either Asian or American ones. The origin country did not significantly affect the ash content in case of cinnamon
\end{abstract}


and/or allspice .Generally, ash content was around( 3-5\%) in different investigated samples. Approximately, it could be seen that Asian spices had higher ash content rather than that of American ones (except of nutmeg from USA). Fiber content of nutmeg did not significantly affect by origin country. $\mathrm{The}(\mathrm{Fe})$ metal was came in the first order; i.e. the predominant one in all of Asian spices except in imported cinnamon, black pepper and allspice from Sri Lanka and China which had $(\mathrm{Mn})$ as a predominant metal . Nutmeg imported from Sri Lanka contains higher level of $(\mathrm{Cu})$ metal that came in the first order followed by its $(\mathrm{Fe})$ level $(3.220 \mathrm{ppm})$. Three of heavy metals were not detected in Asian spices (As, Ti and Li).Concerning the total heavy metals content in different investigated Asian spices,the highest heavy metals content was found in nutmeg that imported from Sri Lanka,while the lowest one was detected in Chinese allspice the similar findings that shown earlier. The Indian black pepper showed the highest TBC content, also Chinese as well as Sri lankian black pepper had a similar high content. Regarding the spices importation origin (American countries), Mexican allspice had the highest TBC. The lowest TBC was detected in case of nutmeg imported from USA.

Keywords: Spices, herbs, nutmeg, cinnamon, black pepper, allspice, heavy metals.

\section{INTRODUCTION}

In the last three decades, mainly because of their medicinal values, the use of spices and other herbs has increased markedly in most regions of the world, including Europe and North America. For instance, during this period, herbal medication in the USA has grown into an industry worth an average of 5billion per year, with projected annual growth of $15 \%$ ( Abebe, 2006).

Human exposure to some heavy metals through consumption of various seasonings in some Ghanaian markets was evaluated. The heavy metals considered were iron $(\mathrm{Fe})$, zinc $(\mathrm{Zn})$, copper $(\mathrm{Cu})$, cadmium $(\mathrm{Cd})$, lead $(\mathrm{Pb})$ and mercury $(\mathrm{Hg})$. The levels of iron $(\mathrm{Fe})$, zinc $(\mathrm{Zn})$, copper $(\mathrm{Cu})$, cadmium $(\mathrm{Cd})$ and lead $(\mathrm{Pb})$ in a total of twenty two (22) mixed and unmixed seasonings were determined using flame atomic absorption spectrometry whereas the mercury 
levels were determined by cold vapour atomic absorption spectrometry. In unmixed seasonings, Fe content ranged from 19.4 to $971.40 \mathrm{mg} / \mathrm{kg}, \mathrm{Zn}$ from 2.40 to $34.60 \mathrm{mg} / \mathrm{kg}, \mathrm{Cu}$ from 0.9 to $10.10 \mathrm{mg} / \mathrm{kg}, \mathrm{Cd}$ from below detection limit (0.01) to $0.9 \mathrm{mg} / \mathrm{kg}$ and $\mathrm{Pb}$ ranged from 0.6 to $1.8 \mathrm{mg} / \mathrm{kg}$. In mixed seasonings, concentration ranged from 83.36 to $480.82 \mathrm{mg} / \mathrm{kg}$ for Fe, 1.72 to $26.78 \mathrm{mg} / \mathrm{kg}$ for $\mathrm{Zn}, 1.73$ to $7.70 \mathrm{mg} / \mathrm{kg}$ for $\mathrm{Cu}$ and 0.63 to $1.39 \mathrm{mg} / \mathrm{kg}$ for $\mathrm{Pb}$ and from below detection limit (0.01) to $0.06 \mathrm{mg} / \mathrm{kg}$ for $\mathrm{Cd}$. $\mathrm{Hg}$ was below the detection limit (0.01) in all the seasonings. The results indicated that $\mathrm{Fe}, \mathrm{Zn}$ and $\mathrm{Cu}$ were below permissible levels whereas $\mathrm{Pb}$ and $\mathrm{Cd}$ were above permissible levels (Darko et al.,2014).

Gulzar et al.(2012) showed differences in metal concentration according to the plant part (Rhizome, seed, leaf and fruit). The concentration ranged on dry basis between ( 6.1-47.0), (56-650), (6-44), (10.5-22.5), (8.5-26.5), (26-88.6), (1.25-14.6) and (0.045-1.35) PPm for the metals, $\mathrm{Zn}, \mathrm{Fe}, \mathrm{Cu}, \mathrm{Cr}, \mathrm{Co}, \mathrm{Mn}, \mathrm{Pb}$, and $\mathrm{Cd}$, respectively. $\mathrm{Pb}$ was above the standard level for cinnamon, the daily intake of $10 \mathrm{~g}$ of spices per day.With the current emphasis on eating more healthy diets that are low in fat and salt, people are turning to various herbs and spices to flavor their food. The culinary herbs and spices that are used to enhance the flavor of vegetables, soups, stir-fry, and pasta dishes can be derived from the bark, buds, flowers, leaves, fruits, seeds, rhizome or roots of a plant (Satter et al., 1989). The presence of essential metals like iron, copper, manganese and zinc are very useful for the healthy growth of the body though very high levels are in tolerable, while metals like lead, cadmium etc. are toxic at very low concentrations. 
These metals may reach and contaminate plants, vegetables, fruits and canned foods through air, water and soil during industrial processing and packaging (Ozores et al., 1997). Monitoring the levels of heavy metal toxicity in spices would help ascertain the health impact of taking these spices, and provide relevant data on spices in the country. Thus, several studies were done to determine the concentration of heavy metals in spices, dry fruits and plant nuts (Husain et al., 1995

Heavy metals have bio-importance as trace elements but the biotoxic effects of many of them in human biochemistry are of great concern.They enter our bodies via food, drinking water and air (Lenntech, 2008).Iron,zinc and copper are essential metals whereas cadmium, lead and mercury have no bio-importance (Divirikli et al., 2006).

Spices can easily be contaminated by heavy metals from type of soil for cultivation ,fertilizers and source of water used for irrigation (Abdullahi et al., 2008).Interaction with sellers of powdered ginger and pepper in the local markets indicated that, these fruits are processed by the individual seller whereas most of the seasonings are imported. These spices may easily be contaminated by heavy metals from the soil or aerial depositions as these spices are dried on the ground or on roof tops.

Use of different herbal compounds and products has increased in recent years for their useful effects on human health (Özcan et al., 2005). Among the most applicable and favorite herbal products, spices can be mentioned as the inseparable components of daily life in various societies. Various vegetal spices are widely applied in human diet all over the world (Mubeen et al., 2009).The most famous of them are including cinnamon,black pepper.Besides using of 
these spices as the flavors for making color and odor in the food,they are also used for their enormous benefits for the human health (Belay, 2014).For example, cinnamon regulates blood sugar and overweight ; black pepper is anticonstipation, removes abscess, toothache, different sunburns and eye problems (Kalicanin and Velimirovic' 2013; Belay et al., 2014; Gulzer et al., 2012).

General attitude among people is that since herbal medicines have natural origins are without danger and the lack of side effects on the consumers .However, since using cultivated herbal medicines in the polluted areas or with improper processing can be one of the entrance ways of dangerous pollutants such as heavy metals to the humans and animals' bodies, controlling them regarding the presence of heavy metals seems necessary ( Nwoko and Mgbeahuruike, 2011; Das et al., 2015).

Regarding biological accumulation capability and longterm consistency in the environment, these elements are toxic for the living organisms even in low concentration and not decomposed in their bodies (Abou-Arab and Abou Donia, 2000 ; Basgel and Erdemoglu, 2006). Metabolism and removing these toxic elements in the body and their absorption is slower, leading to the toxicity, diseases and even death of living organisms depending on their entered values (Soylak et al., 2004; IARC, 2016).

This work therefore seeks to bridge that gap by providing information on the level of heavy metals of these most consumed seasonings. Information will further be provided on the sources of these seasonings and the extent to which they are contaminated with these heavy metals. The effect of cultivation origin (importation area ; i.e American and /or Asian origins)was studied to determine 
the heavy metals content in addition to bacterial load of four imported spices (nutmeg, cinnamon, black pepper and allspice ) avilabale in Egyptian market.

\section{MATERIALS AND METHODS}

\section{Materials:}

Spices: Samples of dry spices including (black pepper, nutmeg, cinnamon and allspice ) that imported from different countries ; i. e. America (USA, Brazil and Mexico) and /or Asia (Sri Lanka, India and China) were obtained from Abou Oof shop, Hyber-one market, El-Sheikh Zayed city, Cairo, Egypt. The used part of the plant, their scientific and comman names are shown in (Table1). Samples were kept in polythene bags and kept in a cool dry cardboard prior to analysis.

Table1: Spice samples with their scientific and common names

\begin{tabular}{|c|c|c|}
\hline \hline Common name & Scientific name & Used part \\
\hline \hline Cinnamon & Cinnamomum verum & Inner bark strips \\
\hline Black pepper & Piper nigrum & Fruit \\
\hline Allspice & Piper cubeba & Fruit \\
\hline Nutmeg & Myristica fragrans & Fruit \\
\hline
\end{tabular}

Methods: Samples were cleaned and oven-dried at $80^{\circ} \mathrm{C} / 12 \mathrm{hrs}$ before chemical analysis. The dried samples were ground, a fine powder was obtained. Powder was sieved with a $0.5 \mathrm{~mm}$ mesh and kept dry for analysis.

Proximate composition: Proximate composition of investigated spices (moisture, total ash, crude fiber, fat and protein) was determined according to A.O.A.C.(2007). While, the amount of total carbohydrates was calculated by difference. 
Analysis of heavy metals: The content of sixteen element (pb, As ,Ti, Li, Al, Mo, B, Cr, Cd ,Ni, Mn, Zn, Co, Cu, Ag and Fe) were determined by digesting with concentrated $\mathrm{H}_{2} \mathrm{SO}_{4}$. Elements were performed according to Kubota and Cary (1982) using ICP instrument Prodigy7.The ICP Specified by Optical Design High Energy Echelle Polychromat or connected with a detector CMOS, available at Central Lab., Fac. Agric., Ain Shams Univ.

Total aerobic plate count: The sample preparation was carried out according to the method described by FAO (1979). $25 \mathrm{~g}$ of sample was homogenized by blending in $225 \mathrm{ml}$ peptone water at $15,000-20,000 \mathrm{rpm}$. This was labeled as 1:10 dilution which is also the stock or the homogenate. This was further serially diluted to $1: 10^{7}$ (Adullahi et al. 2004).

\section{RESULTS AND DISCISSION}

Proximate composition: The proximate composition of different investigated spices (nutmeg, cinnamon, allspice and black pepper) imported from various origins was given in (Table2). Moisture content did not affect according to its origin; i.e. various samples had moisture content ranged between (9.96 to $11.36 \%$ ) in case of nutmeg. Regarding to cinnamon spice, moisture content possess no difference when it determined in either China (9.62\%) or Mexico $(10.78 \%)$ origin. Similar pattern was detected in case of Sri Lanka as well as India (from Asia) and Brazil (from America). In addition, cinnamon imported from China did not differed from that of Mexico one.

When allspice was considered, only that imported from India did not significantly differed with corresponding one that imported from Mexico. In the 
same time (USA) sample was completely significantly differed than that of other investigated samples.

Finally and with regard to black pepper spice that considers as one of imported spice consumes by Egyptians, the same (Table 2) indicated that Mexican and Brazilian samples were significantly differed from other samples that insignificantly different. From the earlier results it could be concluded that moisture content was dependable on spices origin,the lowest moisture content in nutmeg (9.96\%) was that imported from Sri lanka in Asia and in cinnamon also (8.39\%). meanwhile, Indian allspice had lowest moisture content (8.67\%). Also black pepper that imported from China had the lowest moisture content $(13.97 \%)$.Generally, it could be noticed that American investigated spices had higher moisture content rather than that of Asian ones, but there no significant difference between them in case of nutmeg ; i.e. origin did not affect moisture content of nutmeg spice .On the other hand, other three investigated spices are significantly differed owing to its origin.

Regarding to the protein content of different investigated spices (Table2), there is no significant difference owing to its origin in case of nutmeg spice. Both of Asian cinnamon as well as allspice spices had no significant as affected by origin country. Similar finding was noticed in case of American black pepper. Protein content was generally ranged between $4.47 \%$ (Indian cinnamon)) and $6.63 \%$ (Brazilian cinnamon).

Concerning the fat content of various imported spices (Table2), significant differences were detected between samples except of American imported cinnamon, so it could be easily reported that fat content was affected by origin country and ranged between $18.83 \%$ (Chinese cinnamon) and 69.00\%(Chinese 
nutmeg).The highest fat content was found in nutmeg either Asian or American ones, it was (66 to 69\%). Meanwhile, other three investigated spices had a moderate fat content ranged between (32 to 46\%). The lowest fat content was recorded in Chinese cinnamon with $(18.83 \%$.)

The origin country did not significantly affect the ash content in case of cinnamon and/or allspice (Table2). Generally, ash content was around (3-5\%) in different investigated samples. Approximately, it could be seen that Asian spices had higher ash content rather than that of American ones (except of nutmeg from USA). 
Table (2): Proximate composition of spices imported from various origins

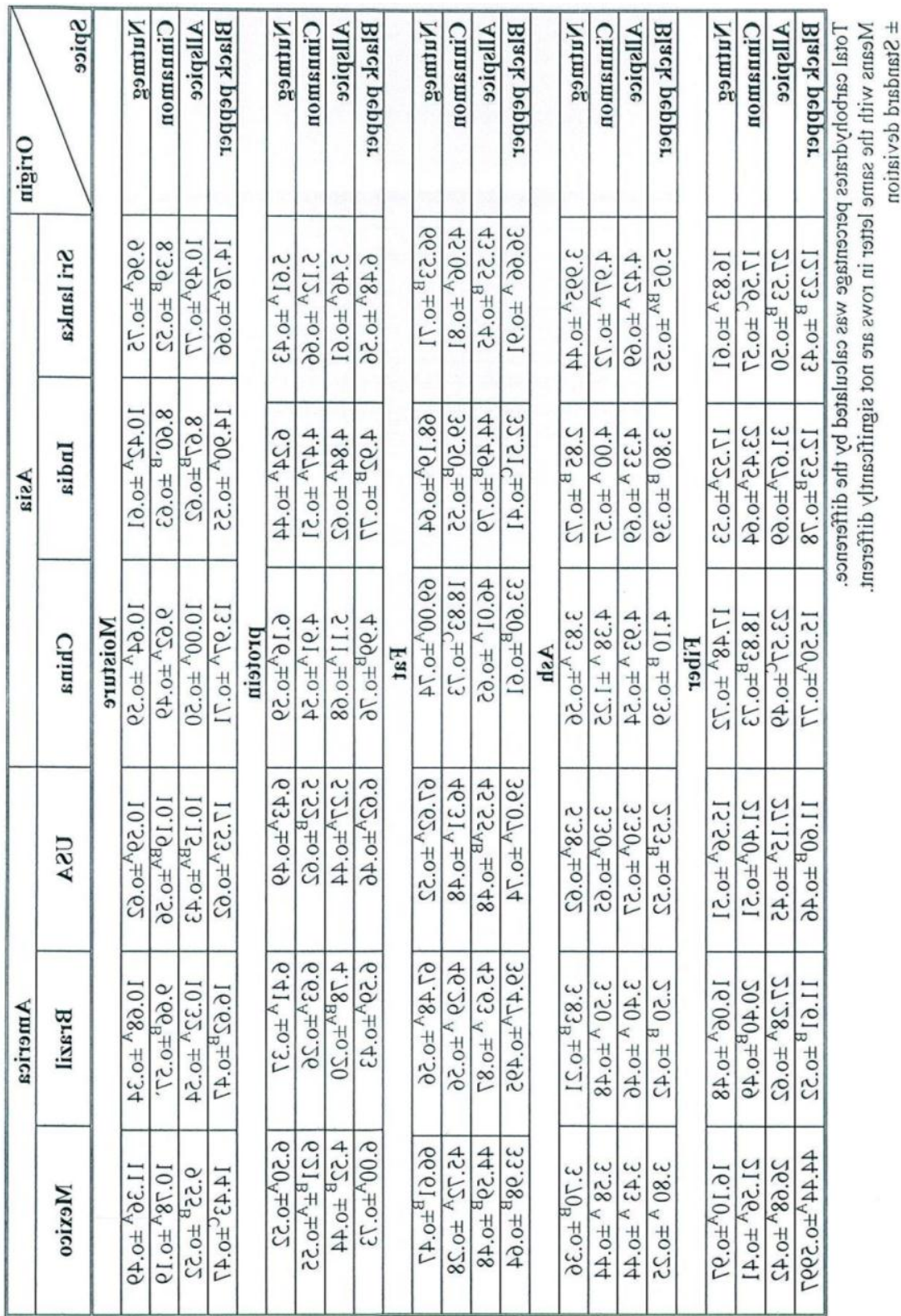


Fiber content of nutmeg did not significantly affect by origin country (Table2). Such finding was also found in case of American allspice samples; i, e. no significant difference was detected between them. The highest ash content was recorded in Mexican black pepper (44.44\%), contrary to the lowest fiber content $(11.60 \%)$ that found in black pepper imported from USA.

\section{Heavy metals content:}

The Heavy metals content in the four investigated spices as affected by their origin countries was followed in Tables (3) and (4). From Table (3) the (Fe) metal was came in the first order ; i.e. the predominant one in all of Asian spices except in imported cinnamon ,black pepper and allspice from Sri Lanka and China which had (Mn) as a predominant metal .It is of interest to notice that nutmeg imported from Sri Lanka contains higher level of $(\mathrm{Cu})$ metal (3.944 $\mathrm{PPm})$ that came in the first order followed by its $(\mathrm{Fe})$ level $(3.220 \mathrm{ppm})$.

Three of heavy metals were not detected in Asian spices (As,Ti and Li).Concerning the total heavy metals content in different investigated Asian spices, the same Table (3) indicated the highest heavy metals content (12.154 PPm) in nutmeg that imported from Sri Lanka, while the lowest one(3.059 PPm) was detected in Chinese allspice .It could be desendingly ordered the other Asian spices according to its total heavy metals content as: Sri Lanka (9.3092 PPm),China (9.2187 PPm), Sri Lanka (9.159 PPm) and India (8.9553 PPm) for cinnamon, allspice and black pepper, respectively (first order).In the second order, India and China had a moderate total heavy metals content (from 6.4331 to $7.591 \mathrm{PPm})$. 
The heavy metals pattern of American origin spices was indicated in Table(4) .Approximately, the similar findings that shown earlier (Table 3) were also noticed in case of imported American spices (Table 4).The iron metal is the predominant metal in most of investigated spices except of cinnamon and black pepper imported from USA, beside Brazilian cinnamon that had (Mn) metal as predominant one with around 2.30 $\mathrm{PPm}$. Regarding the iron content, it was ranged between 0.44 PPm (Brazilian cinnamon) to 7.50 PPm (Brazilian black pepper), it means that Brazilian black pepper had higher $(\mathrm{Fe})$ content with 1.73 fold rather than that of Indian one. The total heavy metals content in American spices was also giving in Table (4). The highest content was detected both of Brazilian and /or Mexican black pepper with about 12.5 PPm. It is of interest to report that the highest total heavy metals content was differed according to the importation origin and the type of spice (Tables 3 and 4); $;$.e. the highest one was detected in Asian nutmeg as well as in American black pepper. Other total heavy metals content in American spices (without black pepper) was ranged between (5.041 and 8.409 PPm). These findings are in line with those of (Gulzar et al.2012; Behnaz and Mohammadreza, 2017). 
J. Environ. Sci.

Institute of Environmental Studies and Research - Ain Shams University

Table (3): Heavy metals concentration (ppm) of investigated spices imported from different Asian origins

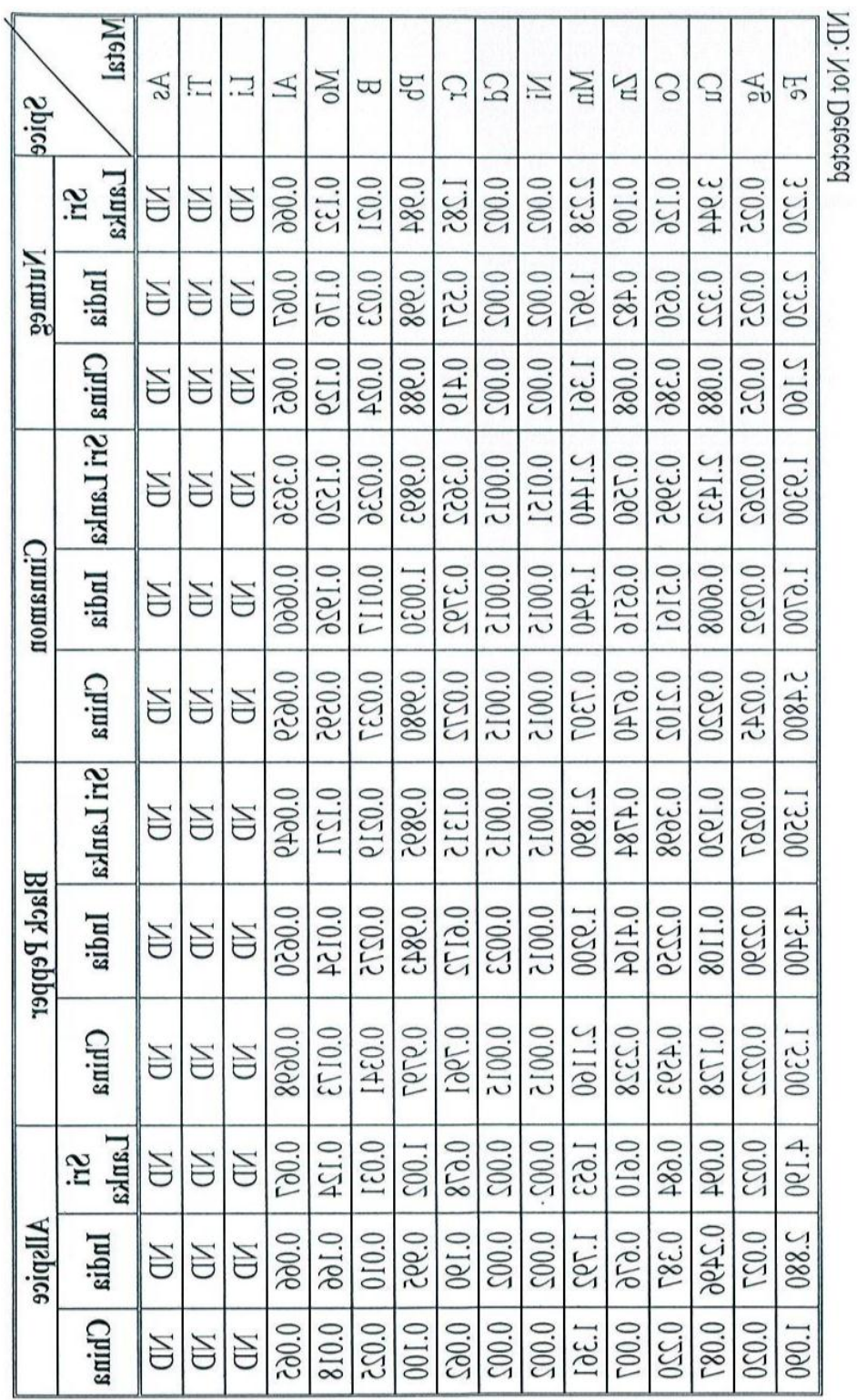

Vol. 48, No.3, Dec. 2019 
Table (4): Heavy metals concentration (ppm) of investigated spices imported from different American origins

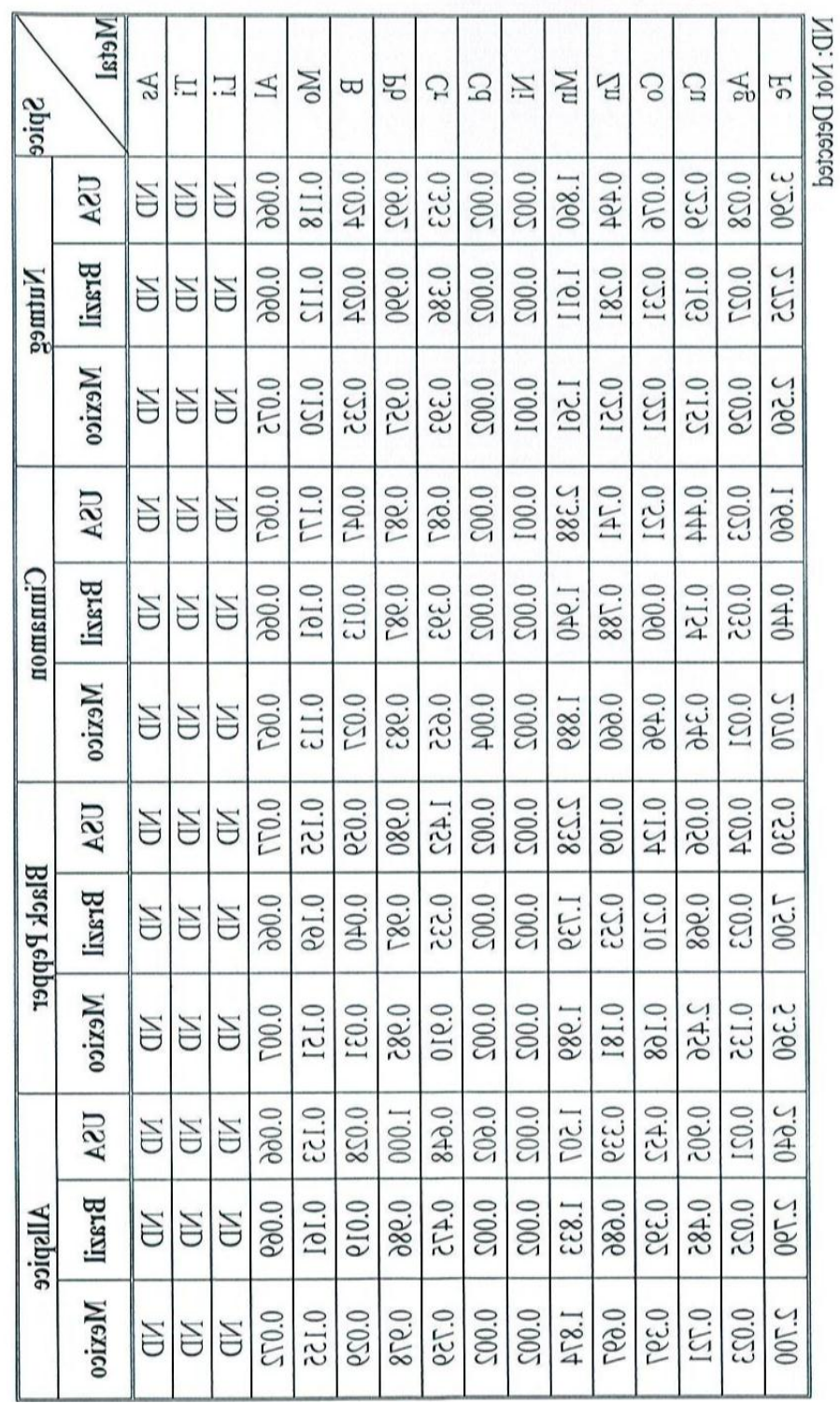




\section{Total bacterial count (TBC):}

The total bacterial count of various collected spices samples was illustreated in Figs.(1) and (2) that from imported Asian and American countries ,respectively. The Indian black pepper showed the highest TBC content (6.49 $\log _{10} \mathrm{cfu}^{\mathrm{ml}} \mathrm{m}^{-1}$ ), also Chinese as well as Sri lankian black pepper had a similar high content $\left(5.4 \log _{10} \mathrm{cfu} \cdot \mathrm{ml}^{-1}\right)$.

Regarding the spices importation origin (American countries), Mexican allspice had the highest TBC $\left(5.93 \log _{10} \mathrm{cfu}^{\mathrm{ml}} \mathrm{l}^{-1}\right)$. The lowest TBC was detected in case of nutmeg imported from USA as shown in Fig. (2).

\section{CONCLUSION}

The effect of cultivation origin ( importation area $; i$ e American and /or Asian origins ) was studied to determine the heavy metals content in addition to bacte -rial load of four imported spices (nutmeg, cinnamon,black pepper and allspice ) avilabale in Egyptian market. The (Fe) metal was came in the first order; i.e. The predominant one in all of Asian spices except in imported cinnamon, black pepper and allspice from Sri Lanka and China which had (Mn) as a predominant metal. Nutmeg imported from Sri Lanka and contains higher level of $(\mathrm{Cu})$ metal that came in the first order followed by its $(\mathrm{Fe})$ level. Concerning the total heavy metals content in different investigated Asian spices, the highest heavy metals content was found in nutmeg that imported from Sri Lanka ,while the lowest one was detected in Chinese allspice .The Indian black pepper showed the highest TBC content ,Mexican allspice had the highest TBC.The lowest TBC was detected in case of nutmeg imported from USA. So, it could be recommended that heavy metals content should be determined in 
imported spices from any of various origin because these spices had hazzard effect when it contained higher level of harmful heavy metals.

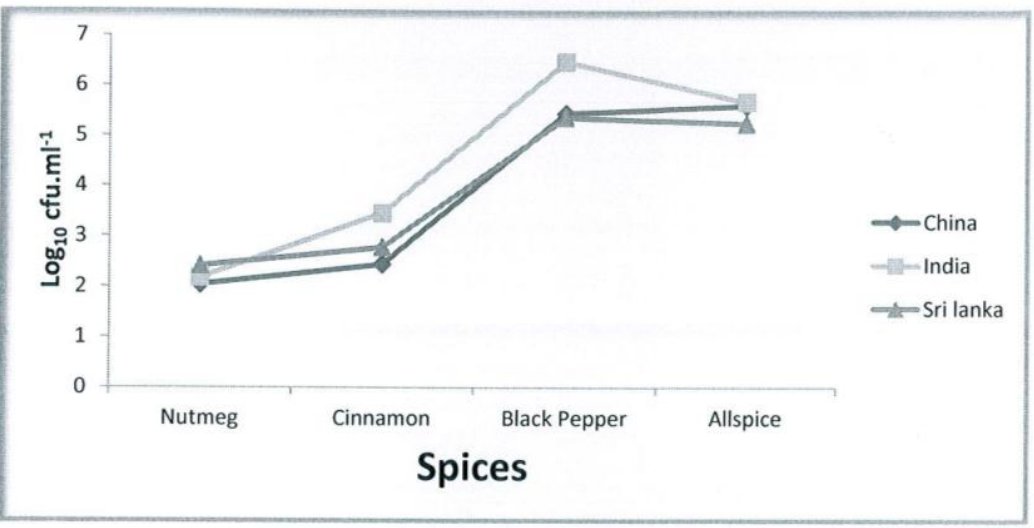

Fig.1 :Total bacterial count (T.B.C) of investigated spices imported from different Asian origins.

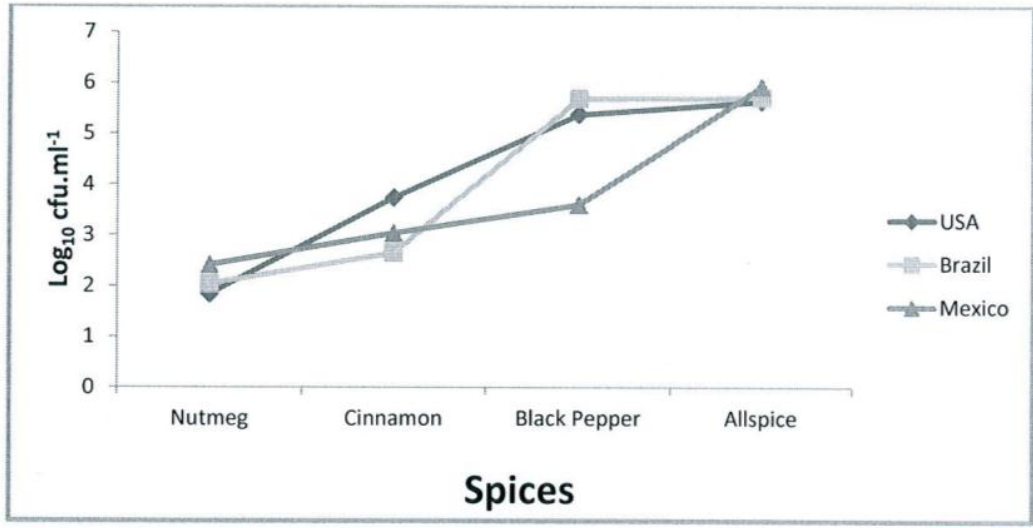

Fig. 2: Total bacterial count (T.B.C) of investigated spices imported from different American origins. 


\section{REFERENCES}

Abdullahi, M.S.; Uzairu, A.and Okunola, O. J. (2008). Determination of some trace metal levels in onion leaves from irrigated farmlands on the bank of River Challawa , Nigeria. Afr. J. Biotechnol ., 7 (10):15261529.

Abebe, W.(2006).Potential health benefits of spices used in Ethiopian cuisines. Ethiop. Med. J.,44 (2), 133-8.

Abou -Arab, A.A .and Abou Donia, M.A. (2000). Heavy metals in Egyptian spices and medicinal plants and the effect of processing on their levels. J Agric Food Chem., 48(6):2300-2304. .

A.O.A.C (2007). Association of Official Analytical Chemists International.Official methods of A.O.A.C International,18 th Edition Gaithersburg. Maryland,USA.

Basgel, S.and Erdemoglu, S.(2006). Determination of mineral and trace elements in some medicinal herbs and their infusions consumed in Turkey.Sci . Total Environ.,359(1):82-89.

Behnaz, B. and Mohammadreza,P.(2017).Evaluating of heavy metal contamination in the most applicable food spices flavors in Hamedan, Iran .J.Arch. Hug. Sci.,6(3):268-275.

Belay, K.(2014). Analysis of lead (pb),cadmium(Cd) and chromium (Cr) in Ethiopian spices after wet (acid) digestion using atomic absorption spectroscopy. Global J. Sci. Front Red, 14(4):1-6.

Belay, K.; Tadesse, A. and Kebede, T.(2014). Validation of a methed for determining heavy metals in some Ethiopian spices by dry ashing using atomic absorption spectroscopy .Int J. Innov. Appl.Stud.,5(2):327-332.

Darko, B.;Ayim,I. and .voeglorlo,R (2014) .Heavy metal content in mixed and unmixed seasonings on the Ghanaian market. African J. Food Sci. ,vol. 8(1), pp. 14-19. 
Das, P.K.; Halder, M.; Mujib, A.S.; Islam, F.; Hahmud, A.M. and Akhter, S. (2015) Heavy metal concentration in some common spices available at local market as well as branded spicy in Chittagong Metropolitan City, Bangladesh. Cure World Environ., 10(1):101.

Divirikli, U.; Horzum, N.; Soylak, M.and Elci, L.(2006). Trace heavy metal contents of some spices and herbal plants from Western Anatolia, Turkey. Int. J. Food Sci. Technol., 41:712-716.

FAO. (1979). Food and Agriculture Organization of the United Nations:Manuals of quality control4.Microbiological analysis D1-D 37.

Gilbert, J. (1984). "Analysis of Food Contamination". 1st edn., Elsevier App. Sci. London .

Gulzar, I.;Ibrahim, G.; Hassan, L.M.;Baban, S.O.and Fadhil, S.S. (2012).Effect of heavy metal content of some common spices available in local markets in Erbil city on human consumption. Iraq. Raf. J. Sci .,23(3): 106-114.

Husain, A.; Baroon, Z.; Al-Khalafawi, S.; Al-Ati, T. and Sawaya, W. (1995).Heavy metals in fruits and vegetables. grown in Kuwait during the oil well fires. Arab Gulf J. Sci. Research,13(3): 535-542.

IARC,(2016). International Agency for Research on Cancer .List of classification by cancer sites with sufficient or limited evidence in humans.p.116:1-12.

Kalicanin, B.and Velimirovic', D.(2013). The content of lead in herbal drugs and tea samples. Cent .Eur. J .Biol.,8(2):178-185.

Kubota, J.and Cary, E.E.(1982).Cobalt ,molybdenum and selenium methods of soil analysis. part2. Chemical and Microbiological properties ,Madison, Wisconsin,USA,pp.485-500.

Lenntech, (2008). Water Treatment and Air Purification. Water Treatment, Published by Lenntech, Rotterdamseweg, Netherlands. www.excel water.com/tho/filters/Water-Purification.htm

Mubeen, H.; Naeem, I.; Taskeen, A.and Saddiqe, Z.(2009).Investigation of heavy metals in commercial spices brands. New York Sci .J $., 2(5): 20-26$. 
Nwoko, C.O. and Mgbeahuruike, L.(2011).Heavy contamination of ready-touse herbal remedies in south eastern Nigeria .Pakistan J. Nuts ., 10(10):959-964.

Özcan, M.; Arslan, D.and Ünver, A. (2005). Effect of drying methods on the mineral content of basil (Ocimum basilicum L. ).J Food Eng., 69(3):375-379.

Ozores, H. M.; Hanlon, E.; Bryan, H.and Schaffer, B. (1997). Cadmium, copper, lead, nickel and zinc concentrations in tomato and squash grown in MSW compost amended calcareous soil. Compost Sci. and Utilization, 5 (4), 40-45.

Satter, A.;Wahid, M.and Durrani, S.K. (1989). Concentration of selected heavy metals in spices,dry fruits and plants nuts.Plant Food Hum. Nutr., 39(4):279-286.

Soylak, M.; Tuzen, M.; Marin, I.and Sari, H.(2004).Comparison of microwave, dry and wet digestion procedures for the determination of trace metal. J Food Drug Anal., 12(3):254-258. 


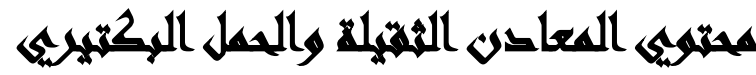

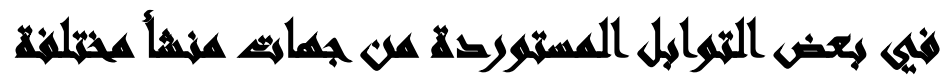

[r]

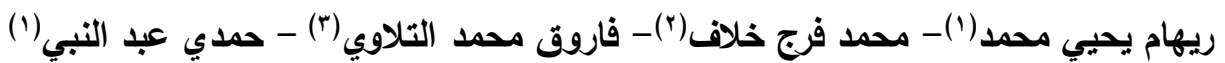

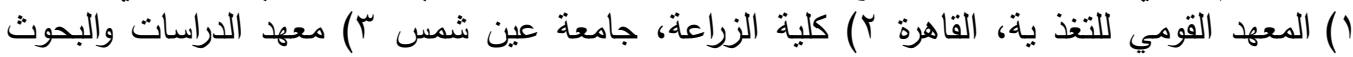

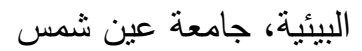

\section{ll}

ازداد مؤخرا استهلاك التوابل والإعشاب زيادة ملحوظة في غالبية أنحاء العالم بما فيها أوروبا وأمريكا

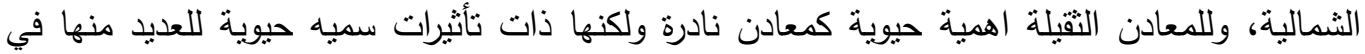

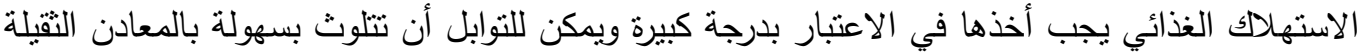

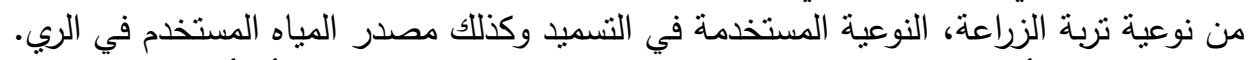

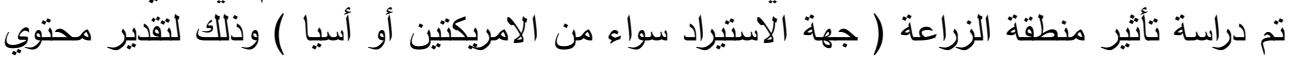

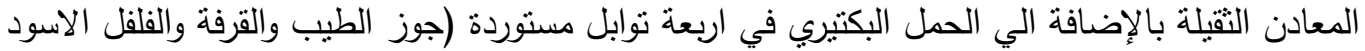

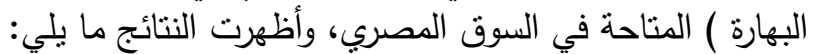

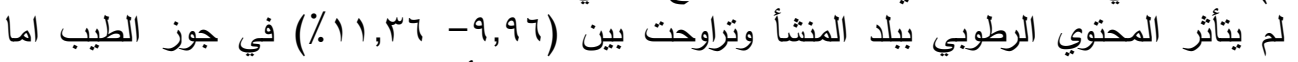

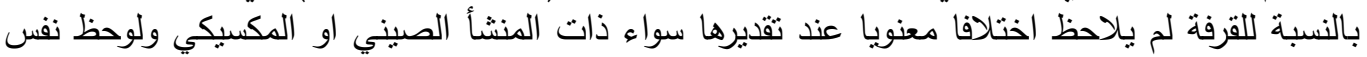

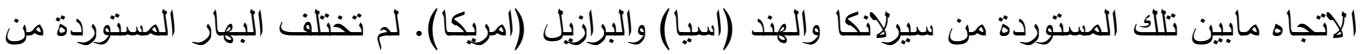

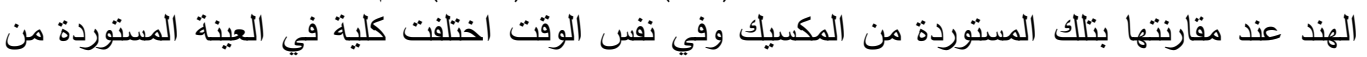

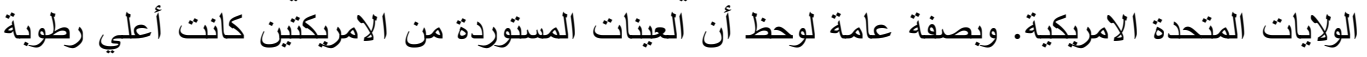

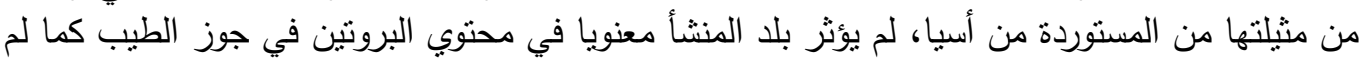

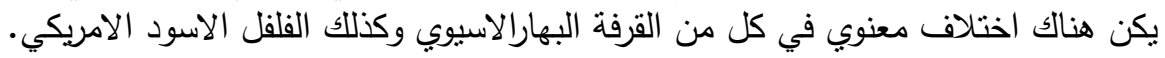

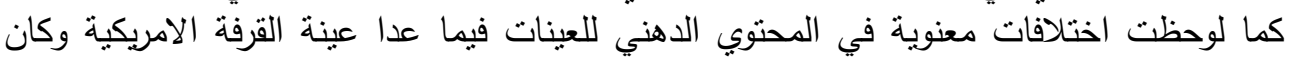

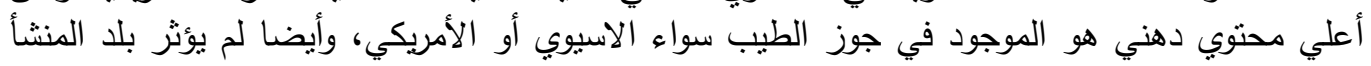

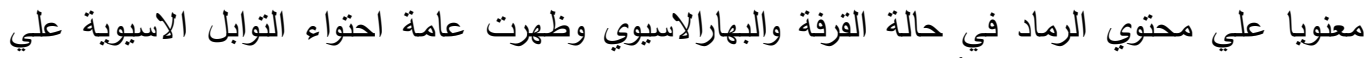

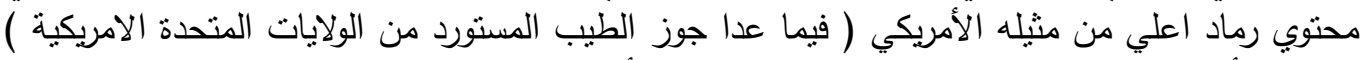

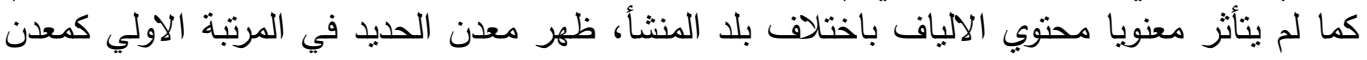

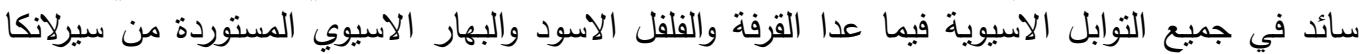

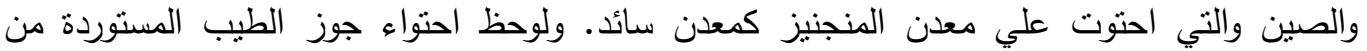

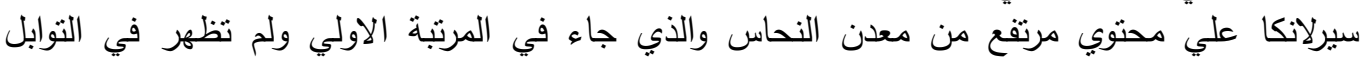

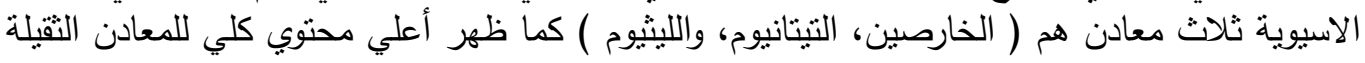

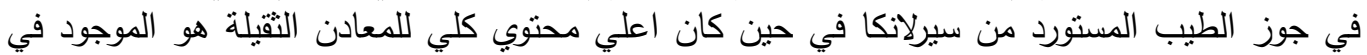
الكبيية الصيني. أظهر الفلفل الاسود الهندي اعلي محتوي بكتيري كذللك الصيني والسيريلانكي واللذان الطين 40

Vol. 48, No.3, Dec. 2019 
J. Environ. Sci.

Institute of Environmental Studies and Research - Ain Shams University

احتويا علي قيم منتابهة. أظهرت البهارالاسيوي المكسيكية أعلي محتوي بكتيري في حين كان أقل محتوي

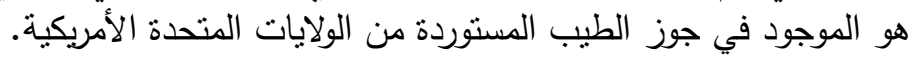

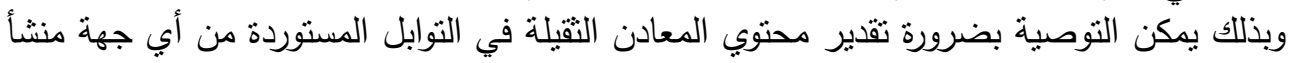
وذلك لإعتبارها مصدرا للخطر في حالة ارتفاع محتواها من المعادن الثقيلة الضارة. 